\title{
Factors associated to managers' belief whether their employees cannot and do not want to work until an older age, and measure activities increasing their employees' possibilities of working in an extended working life.
}

Kerstin Nilsson ( $\square$ kerstin.nilsson@med.lu.se )

Lund University https://orcid.org/0000-0002-3193-205X

\section{Emma Nilsson}

Lunds Universitet

Research article

Keywords: human resource, managers, employees, motivation, swAge, organisation, older worker, health, retirement, work environment

Posted Date: April 29th, 2020

DOI: https://doi.org/10.21203/rs.3.rs-22885/v1

License: (c) (1) This work is licensed under a Creative Commons Attribution 4.0 International License. Read Full License 


\section{Abstract}

Background: The demographic situation with an increasing number of elderly citizens will postpone the retirement age in most countries. However, retirement is a socially accepted way to withdraw from a demanding working life.

Objectives: The aim of this study was to evaluate the main factors associated to managers' beliefs their employees want to or can work until 65 years of age or beyond, and measures increasing participation in an extended working life.

Methods: The baseline survey in a follow up study including 249 managers in the municipality sector in Sweden. By logistic regression we investigated the associations between two outcome measures: i) whether employees wanted to work, and ii) whether employees could work until 65 years of age or beyond, and statements within nine areas related to a sustainable working life as well as measure statements for an extend working life.

Results : Of the mangers $79 \%$ stated their employees 'can' and 58\% that their employees 'want to' work until 65 years of age or beyond. The employees' health, physical work environment, skills and competence were statistically significant to the mangers' belief that their employees could not work until 65 years of age or beyond. Lack of support in the social work environment and lack of possibilities to arrange relocations were the most important factors to managers' beliefs whether employees would not want to work until age 65 or beyond.

Conclusion: To offer the employee other tasks in the workplace if needed was a measure statistically significant associated to increase the managers' belief whether their employees both could and wanted to go on and work until 65 years of age and beyond. Additionally, the managers' belief measures to decreased physical and mental strains and rotation between different tasks to reduce work load and wear would increase whether their employees can work, and reduction of pace and working hours would increase whether employees want to work in an extended working life past 65 years of age. The managers' perspective on how their employees 'can' and 'want' to work will hopefully contribute to the understanding of the extended working life process.

\section{Background}

Retirement is a possible and socially acceptable way for employees to withdraw from working life, e.g. from a physically and mentally demanding work situation, if the private finances will sufficient with pension, if anyone does not want to continue working due to the social situation and environment at the work place or because their skills not being used in the work tasks and or not experiencing drive and stimulation from the work tasks $(1,2)$. However, the fraction of older people is continuously increasing in most of the industrial world (3). Longevity and lower fertility characterise the current demographic trend and is leading to an increasingly ageing population. A consequence analysis carried out by the Organization for Economic Co-operation and Development (OECD) compared the elderly boom to have 
economic and budgetary implications like the social effects arising from natural disasters (3). The increasing older population means more people in the pension system, and the demographic change will give an increased old age dependency ratio when fewer citizens in the workforce must provide for an increasing number of elderly citizens. Retirement ages in many countries are being postponed as a way of adapting to the new demographic distribution. Older people are encouraged to go on and participate in the labor force for as long as possible (3-6). This demographic situation stresses the importance of factors motivating older employees to experience that they can and want to work until an older age.

Managers have a key role in how to motivate and make measures in the work situation to enable employees to extend their working lives. However, what are the determinant factors for work force participation and for a sustainable working life? Earlier studies have identified nine determinant areas connected to whether people can and want to work in an extended working life or not $(1,7-36)$. Those nine areas is also described in the theoretical swAge-model (Sustainable working life for all ages) and are: 1) self-rated health, diagnoses, function variation; 2) physical work environment; 3) mental work environment; 4) work schedule, work pace, recuperation; 5) private economy; 6) private social environment; 7) work social environment; 8) work tasks, stimulation, motivation, self-crediting; 9) knowledge, skills, competence. Good health is a very important factor to whether people are able to work, or to take sick leave or some form of retirement $(1,7-12)$. Poor physical work environment and work conditions increase the risk of work accidents, leave people worn out and push them to leave working life early $(1,7-9,13-15)$. Mental work conditions, stress and lack of job control have also been mentioned as important predictors for people's sick leave and retirement planning $(1,7-9,16-18)$. Some studies highlight moderate working pace and working hours as very important for a sustainable working life and for the older workforce, and have also shown that older workers seem to need more time for rest and recuperation $(1,7-9,19-21)$. Another factor often described in relation to early retirement is personal finances, i.e. incentives that keep employees in the workforce through the risk of poverty or make it possible to stop working within sufficient financial well-being $(1,7-9,22-24)$. The private social environment and attitudes in the surrounding society also influence withdrawal from working life, for example marital status, whether the life partner is working or if the older worker wants to spend more time with relatives and leisure pursuits $(1,7-9,25-27)$. The social work environment and situation is also of great importance. What the management and leadership in the company is like, whether the attitude is positive towards and between employees, whether workers are treated as included in the organisation, or whether there is a stereotypical idea of elderly workers as stagnant and an encumbrance $(1,7-9,28-30)$. A feeling of satisfaction with the work tasks, the daily work as well as receiving attention, wisdom and experience in the work situation have also been cited as important factors in the intention to extend working life $(1,7-9,31-33)$. Another factor that affects the decision to stay or go according to previous research is the level of education, competence and possibility of skill development, but also whether employees are able to use their skills in their work tasks $(1,7-9,34-36)$. To better understand how managers could motivate employees and make working life more sustainable until an older age, it is of particular interest to examine managers' beliefs on whether their employees 'can' and 'want to' work until an older age, associated with the nine areas. 


\section{Methods}

The aim of the present baseline study, among managers in municipality organisations, was to evaluate the main factors associated to managers' belief whether their employees want to, or can, work until 65 years of age or beyond. The aim was also to investigate which measure the managers believe could increase their employees' ability and wish to work in an extended working life.

The dataset used in this study originated from a baseline survey conducted in 2018, in a longitudinal study with municipality managers. The survey examined managers' attitudes toward their employees and factors of interest for work participation and retirement.

\section{Study population}

Working in the public sector has been associated with early withdrawal from working life in a previous study $(37,38)$. The study population consisted of all managers in one of the largest municipalities in Sweden. The 456 subjects were identified by the personnel register as employed and employed as manager. The study population all had the same employer, which minimised the risk of different employment conditions, rehabilitation policies and retirement policies (39). The individuals in the present study were sent a questionnaire through their work electronic mail. After two reminders, 249 individuals answered the questionnaire. This corresponded to a response rate of $54,6 \%$.

The gender distribution of the study population was $29 \%$ male managers and $71 \%$ female managers. The age distribution in the study group was $25-67$ years of age, with an average age of 50.4 years. $96 \%$ of the study population worked $40 \mathrm{~h} /$ week (full-time), and $90 \%$ were managers in a full-time position. The distribution of the managers sectoral work areas was: $38.6 \%$ Educational work (child, adolescent and adult education); $14.5 \%$ Care, health care, rehabilitation work, housing, home service; $11.6 \%$ Social and curative work; $9.2 \%$ Technology, IT, city environment, water maintenance, electric operation maintenance, kitchen and food distribution; 4.4\% Library, archive, culture, tourism, municipality leisure activities; $21.7 \%$ Administration, support functions (HR, finance, law, administrative support function, management, communication, digitization).

\section{Questionnaire}

Two questions formed the basis for the outcome in this study. The first question was whether the responding managers thought their employees wanted to work until 55-59, 60-64, 65 or 66 years of age or beyond, and the second question was whether the responding managers thought their employees could work until $55-59,60-64,65$ or 66 years of age or beyond. The answering options were dichotomised at 65 years of age (i.e. working until $<65$ versus $\geq 65$ years of age).

The questionnaire was developed in the research group and tested and used before in other studies, the first time in a group of 905 responding mangers in year 2006. The questions were sorted into the nine areas in the swAge-model: 1) self-rated health, diagnoses, function variation; 2) physical work environment; 3) mental work environment; 4) work schedule, work pace, recruitment; 5) private finances; 
6) private social environment; 7) work social environment; 8) work tasks stimulation, motivation, selfcrediting; 9) knowledge, skills, competence.

\section{Statistical analysis}

Logistic regression models generating odds ratios (OR), 95\% confidence intervals (CI) and p-values were used to investigate the statements associated with the outcomes of the managers' belief that their employees 'want to work until 65 years of age or beyond' and 'can work until 65 years of age or beyond'. For each of the two outcomes, we used the following analytical strategy:

1) Analyses within each of the nine areas: We started with univariate analyses, i.e. we evaluated the associations for one statement at a time. In the second step we kept the statement with the lowest pvalue (if $\mathrm{p}<0.05$ ) and tentatively included all other statements, one at a time. In the third step we kept the two statements with the lowest $p$-values (if both $p<0.05$ ) and tentatively included the remaining statements one at a time. This procedure continued for as long as the $p$-values for all included statements were $<0.05$.

2) Analyses including all nine areas: The multivariate model for all determinant areas together started by including the selected statements from area 1) and area 2) etc. to build a multivariate model. The statements with p-values $<0.05$ were kept in the model in the next step, in which we also included the selected statements from the next area. This procedure continued until all nine areas were included in a final model. After that, the discarded statements from the nine areas were tested, one at a time, against the final model, to check once more whether the model was robust.

3) Measure variables: To examine the measure variables associated to the managers' belief that their employees can and want to work in an extended working life the same procedure was used univariate analyses, i.e. we evaluated the associations for one statement at a time. In the second step we kept the statement with the lowest $p$-value (if $p<0.05$ ) and, if there were more than one statement in the areas, tentatively included other statements one at a time. This procedure continued for as long as the $p$-values for all included statements were $<0.05$.

In the results section of the paper below, the univariate and the statements in the final models are presented.

\section{Results}

\section{Outcomes}

The managers were asked when they experienced their employees to be older workers. The median age for an older female worker was 60 years of age according to the managers' rating responds, and the median age for an older male worker was also 60 years of age according to the managers' ratings. 
The managers stated different ages to be the possible general retirement age for their employees, i.e. until what age in general they believe their employees can work and want to work. The proportion of managers who stated that most of their employees 'can work until 65 years of age or beyond' was $77 \%$ (Table 1). The proportion of managers who stated that most of their employees 'wanted to work until 65 years or beyond' was $58 \%$ (Table 2). However, the proportion of responding manager stating that they themselves could work until 65 years of age or beyond was $86 \%$. The proportion of managers wanting to work until 65 years of age or beyond was $43 \%$.

\section{Statements associated with managers' belief that their employees in general 'cannot work until 65 years of age or beyond'}

The statements from the nine determinant areas was analysed with logistic regression analysis to identify the association between the statements and managers belief that their employees in general cannot work until 65 years of age or beyond (Table 3). Both statements univariate estimates in the area "health, diagnoses, function variation" was statistically significant associated with whether the managers believed that their employees could not work until 65 years of age or beyond, i.e. "The majority of my employees have some kind of diagnosis or chronic disease", "The majority of my employees do not seem to experience well-being in their daily life". Both statements were statistically significant and included in the final multivariate model in the area. Of the seven statements univariate estimates in the area "physical work environment" five were statistically significant to the managers' belief that their employees could not work until 65 years of age or beyond. However, only two statements were finally statistically significant and included in the multivariate model of the area, i.e. "I experience that my employees in general have many tasks involving a physically demanding work load and heavy lifting", "I do not experience that my employees have a reasonable physical work load". The area "private finances" consists of only one statement that was statistically significant to the managers' belief that their employees could not work until 65 years of or beyond, i.e. "I experience that my employees in general feel pressured by their financial situation". In the area "work social environment" two of seven statements univariate estimates were statistically significant and associated to whether the managers believed that their employees could not work until 65 years of age or beyond, and therefore included in the multivariate model, i.e. "My employees in general do not receive sufficient support from me to be able to work until ordinary retirement age", "I am not satisfied with the extent of support that I offer my employees for them to be able to cope with their work tasks". Three of the seven statements in the area "work task stimulation, motivation, self-crediting" univariate estimates were statistically significant and associated with whether the managers believed that their employees could not work until 65 years of age or beyond, i.e. "I do not experience it being possible to adjust work tasks to elderly employees in my organisation", "In my experience it is hard to find work tasks to relocate employees who experience their work environment as too physically demanding" and "In my experience it is hard to find work tasks to relocate employees who experience their work environment as too mentally demanding". However, only one of these 
statements was statistically significant in the final multivariate model in the area, i.e. "I do not experience it being possible to adjust work tasks to elderly employees in my organisation". In the area "competence, skills, knowledge development" three of seven statements univariate estimates were statistically significant but only one statement, "I do not experience that my employees have access to sufficient technical support", was statistically significant and included in the final result after the multivariate modelling. There were no statistically significant associations in the areas "Mental work environment", "Work schedule, work pace and recuperation" and "Private social environment" to whether the mangers believed that their employees could not work until 65 years of age or beyond.

In the final multivariate model of all areas five statements were statistically significant and associated with whether the managers believed that their employees could not work until 65 years of age or beyond (Table 4). The statements came from three of the nine areas. One statement came from the area "Health, diagnoses, function variation", two from "Physical work environment" and one statement came from the area "Competence, skills, knowledge development". The strongest observed association in the multivariate model was for the statement "I do not experience that my employees have a reasonable physical work load" followed by "I experience that my employees in general have many tasks involving a physically demanding work load and heavy lifting", "I do not experience it being important to keep elderly employees in the organisation based on their competence", "I do not experience that my employees have access to sufficient technical support", "The majority of my employees have some kind of diagnosis or chronic disease"

\section{Measure activities to enable employees' ability to work until 65 years of age or beyond}

In the next step a logistic regression analysis was used to investigate 28 possible measure activities associated to managers' belief that their employees can work until 65 years of age or beyond. The measure activities were related to eight of the nine determinant areas, i.e. no measure activity was related to the area "Private social environment". The highest statistically significant corresponding odds ratio (OR) was that of the measure activities "Decrease of physical work demands"; "Other work tasks in the workplace"; "Rotation between different work tasks to decrease physical work load and strain" in association to managers' belief whether their employees could work until 65 years of or beyond. Additionally, the measure activities "Rotation between different work tasks to decrease mental work load and strain" and "Decrease of mental work demands" were statistically significant and associated to managers' belief whether their employees could work until 65 years of age or beyond.

\section{Statements associated with managers' belief whether their employees in general 'do not want to work until 65 years of age or beyond'}


To identify the association between the statements from the nine determinant areas and managers' belief whether their employees in general not want to work until 65 years of age or beyond the association was analyses through logistic regression analysis (Table 6). In the determinant area "Health, diagnoses, function variation" one of the two statements univariate estimates was statistically significant, i.e. "The majority of my employees have some kind of diagnosis or chronic disease", and included in the final multivariate model in the area. In the area "Physical work environment" one of the seven statements univariate estimates was statistically significant, i.e. "In my experience it is hard to find work tasks to relocate employees who experience their work environment as too physically demanding", and included in the final multivariate model. In the area "Mental work environment" one of the six statements univariate estimates was statistically significant and associated to whether the managers believe that their employees do not want to work until 65 years of age or beyond, i.e. "I do not experience that there is a general balance between the demands put on my employees in their work, and the control they have in executing their work tasks". In the area "Work schedule, work pace and recovery" two of four statements were statistically significant to whether the managers believed that their employees would not want to work until 65 years of age or beyond, i.e. "I do not experience that my employees in general have sufficient opportunity of taking breaks when working" and "I do not experience that my employees in general have a good work schedule that enables recuperation between work shifts". However, only the statement "I do not experience that my employees in general have sufficient opportunity of taking breaks when working" was statistically significant and included in the modelling of the final multivariate model of the area. In the area "Work social environment" one of seven statements univariate estimates was statistically significant and associated to whether the managers believed that their employees would not want to work until 65 years of age or beyond and therefore included in the multivariate model, i.e. "My employees in general do not receive sufficient support from me to be able to work until ordinary retirement age". One of the four statements in the area "Work tasks stimulation, motivation, self-crediting" univariate estimates was statistically significant associated with whether the managers believed their employees would not want to work until 65 years of age or beyond, i.e. "I do not experience it being possible to adjust work tasks to elderly employees in my organisation". In the area "Competence, skills, knowledge development" one of seven statements univariate estimates was statistically significant but only one statement, "I do not experience that my employees have access to sufficient technical support", was statistically significant and included in the final model after the multivariate modelling. There were no statistically significant associations in the areas "Personal finances" and "Private social environment" to whether the managers believed their employees would not want to work until 65 years of age or beyond.

In the final multivariate model of all areas and whether the managers believed that their employees would not want to work until 65 years of age or beyond, two statements were statistically significant and associated (Table 7). The statements came from two of the nine areas. One statement came from the area "Work social environment", and one statement from the area "Work tasks stimulation, motivation, self-crediting". The strongest observed association in the multivariate model to whether the managers believed their employees would not want to work was the statement "My employees in general do not 
receive sufficient support from me to be able to work until ordinary retirement age", followed by "In my experience it is hard to find work tasks to relocate employees who experience their work environment as too physically demanding".

\section{Measure activities to enable employees being able to work until 65 years of age or beyond}

In the next step the 28 possible measure activities were analysed in association to managers' belief that their employees want to work until 65 years of age or beyond. The different measure activities were related to eight of the nine determinant areas, i.e. no measure activities related to the area "Private social environment". The highest statistically significant corresponding odds ratio (OR) was that of measure activities in the area "Work schedule, work pace, recovery", i.e. "Decrease of work pace" and "Increased time for recuperation between work shifts" in association to managers' beliefs that their employees want to work until 65 years of age or beyond. Also the measure activity in the area "Work tasks stimulation, motivation, self-crediting" i.e. "Other work tasks in the workplace when needed", was statistically significant and associated to whether managers believe that their employees want to work until 65 years of age and beyond.

\section{Discussion}

This study indicates that there is a difference between factors associated to whether managers believe that their employees 'can work' and 'want to work' in an extended working life. A larger proportion of managers believed their employees would be able work compared to wanting to work until age 65 or beyond. Additionally, a larger proportion of managers themselves believed that they 'can work' rather than that they 'want to' work until age 65 or beyond. The nine determinant areas chosen to cover the field of factors associated to an extended and sustainable working life were based on the swAge-model (8). All nine areas in the analysis has been identified in previous studies as very important to retirement and retirement planning $(1,7-36)$. The investigation analysis regarding which of the nine determinant areas was mostly important to whether managers believed their employees can and want to work in an extended working life. The multivariate model stated that three of these areas were statistically significant and specially associated with mangers' belief whether their employees could not work until 65 years or beyond, i.e. "health, diagnoses, function variation”, "physical work environment" and "competence, skills, knowledge development". The results of the multivariate model also stated that two of these areas were statistically significant and specially associated with mangers' belief whether their employees would not want to work until 65 years or beyond, i.e. "work social environment" and "work task stimulation, motivation, self-crediting". These results stated the robustness of the earlier studies and theory of those determinant areas being related to whether individuals can work respectively want to work in an extended working life (Nilsson et al, 2011; Nilsson 2016). 
The study design seems to be cross sectional, but is actually the baseline measurement in a longitudinal study regarding factors effecting an extended working life. The questionnaire was sent out after a review of the theoretical basis in the area, the swAge-model (7-10), and the majority of the statements in the questionnaire have previously been validated and used in a previous study (29). Although the municipal community included in the study was the eighth largest in Sweden with 456 managers of participation identified to the study, a potential weakness was that $46,4 \%$ of the managers in the original study population did not participate. However, the participation rate was $54.6 \%$, compared to other studies this was an expected and normal participation rate of surveys. In the Swedish municipality studied there are mostly female employees, which corresponded with that most of study population and the respondents were women.

The attitude towards working until an older age has changed in the last years in Sweden. A larger proportion of Swedish municipality managers in this 2018 survey, compared to a survey with Swedish municipality managers in 2007, believed that they themselves could work until 66 years of age or beyond. More specifically, in year $200764,5 \%$ of the managers stated that they could work until 55-65 years of age and $35,5 \%$ to 66 years of age or beyond compared to 2018 when $36,9 \%$ stated they could work until $55-65$ years of age and $63,1 \%$ until 66 years of age or beyond $(40,41)$. Additionally, a larger proportion of managers in 2018 want to work until an older age than in 2007, i.e. in year $200785,5 \%$ wanted to work until $55-65$ years of age and 14,6\% until 66 years of age or beyond, compared to 2018 when $80,7 \%$ until $55-65$ years of age and $19,3 \%$ until 66 years of age and beyond $(40,41)$. In this study, the managers' attitude towards when individuals were elderly employees was in mean 60 years of age, both for male and female employees. However, in another Swedish study with 905 municipality managers, it emerged that the managers on average considered both their male and female employees to be elderly employees at age 59 (29). In a study from the UK, managers defined their female employees as elderly employees from 48 years of age, while male employees were listed as older employees from 51 years of age (42).

This study analyses which of the nine determinant areas was mostly important to whether managers believed their employees would be able to and would want to work in an extended working life. Individuals health situation, i.e. the area "Self-rated health, diagnoses and function variation", is very important to whether individuals can participate in working life at all $(1,7-12)$. In the univariate estimates the determinant area "Health, diagnoses and function variation" was statistically significant to whether managers believed their employees could not work in an extended working life. However, in this study the managers related to their employees who were a part of working life at the moment, and most of the managers (93\%) believed their employees to have a good well-being and health status in their daily lives. Therefore, the good health situation among employees in this study has an effect on the final model of factors related to whether managers believe their employees could work until 65 years of age or beyond. Still, in other work places the health status among employees could have a greater effect as determinant area to whether an individual could work until an older age or not.

The determinant area "Physical work environment" was statistically significant both in the univariate and in the final multivariate model of all nine areas associated with whether managers believe their

Page 10/31 
employees could work until 65 years of age and beyond. Earlier studies states the physical work environment to have an effect on an individual's health, withdrawal from working life and that a demanding physical work environment could rapidly increase biological ageing $(1,7-9,13-15)$. The analysis of measures in this study stated that the most important measures associated with whether managers believe they could enable employees to work in an extended working life, i.e. the highest statistically significant OR, were measures in the area "Physical work environment", to decrease the physical demands and to rotate between different work tasks to decrease strain and physical demand.

The determinant area "Mental work environment" in this study was in the univariate model statistically significant related to whether managers believed their employees would not want to work until an older age. Earlier studies states the mental work environment and balance between demand and control in the work situation to be very important to work related stress (43). Additionally, the mental work environment has been stated as important to the employees' own attitudes towards an extended working life (1, 7-9, $16-18)$. In the analysis of managers' belief in different measures to increase employees ability to work until 65 years of age or beyond in this study, the determinant area "Mental work environment" was statistically significant to whether managers believed their employees could work in an extended working life, i.e. measures to decrease the mental demands in the work situation and measures to promote rotation between different work tasks to decrease the strain of mental demands.

The determinant area "Work schedule, work pace and recuperation" in the univariate model in this study was statistically significant and related to whether managers believed their employees did not want to work until an older age. Measures in work schedules to decrease working hours with an older age may affect the extension of working life to an older age according to previous studies $(1,7-9,19-21)$. Measures to decrease the work pace and measures to increase the possibility of recuperation between the work shifts were also the most important, i.e. with the highest statistically significant OR, regarding what the managers believed could increase the employees' possibility of wanting to work until 65 years of age or beyond in this study.

The determinant area "Financial incentives" are previously well-known factors to pull and push older workers to retirement or to an extended working life $(1,7-9,22-24)$. Compared to the other determinant areas examined in this study, financial incentives were statistically significant to whether managers believed their employees could work until an older age. In spite of this, financial incentives were not statistically significant to whether the managers believed their employees could not or did not want to work until 65 years of age or beyond in the final models.

The determinant area "Private social environment" was not statistically significant in the univariate estimates regarding factors associated to what manages believe would effect whether their employees could not and did not want to work in an extended working life, or in the multivariate model with all the determinant areas. However, studies with employees' own attitudes towards an extended working life stated that factors regarding private life, such as when a partner retires, is important to the individual decision whether to work in an extended working life or not $(1,7-9,18,25-27)$. This indicated that the 
managers most probably focus on the work situation and not as much on the fact that employees also have a life beside the work life that influence whether they can and want to work.

The determinant area "Work social environment" was statistically significant in the univariate estimates to both whether the managers believe their employees cannot and do not want to work in an extended working life. However, it was only statistically significant to whether managers believe their employees would not want to work until 65 years of age, and not to whether they believe their employees would be able to work, in the multivariate models of all the determinant areas. Actually, whether the employees did not receive enough support from their managers was the most important, i.e. the highest statistically significant $O R$, in the multivariate model of all determinant areas to whether the managers believe their employees would not want to work in an extended working life. The manager has got a very important role and decision power regarding measures, norms and strategies in the workplace and to enable individual employees to work in an extended working life $(1,7-9,18,28-30)$. It is therefore important that the managers' attitudes towards elderly employees is positive, if society wants more people to get a chance to stay in working life until an older age due to the demographic development where more elderly people need to earn a living.

The determinant area "Work tasks, stimulation, motivation, self-crediting" was statistically significant in the univariate estimates to whether the managers believed their employees both would not be able to and would not want to work until 65 years of age and beyond. This determinant area was also statistically significant to whether the managers believed their employees would not want to work in an extended working life in the multivariate model of all the determinant areas. Additionally, the measure to arrange other work task in the work place for the employee when necessary was highly associated, i.e. high statistically significant $O R$, to that the manager believed their employees would increase their ability to both being able to and wanting to work in an extended working life. Individuals need activities, according to previous studies motivating and simulating tasks has an impact on employees to increase their participation in an extended working life (1, 7-9, 31-33). Possibilities of changing work tasks if necessary is also important for an ongoing employability until an older age.

Statements in the determinant area "Competence, skills, knowledge development" was statistically significant in the univariate estimates to both whether managers believe their employees would not be able to and would not want to work until 65 years of or beyond. The area was also statistically significant in the multivariate model of all the determinant areas and whether managers believe their employees would not be able to work in an extended working life. If the managers' attitudes and experiences were that they need the competence of elderly employees and additionally to arrange knowledge and competence development in a way that fit the elderly employees cognitive ageing, the elderly employees increase their willingness and skills to keep working in an extended working life (1, 7-9, 34-36). However, in this study the managers do not seem to regard competence as a measure to increase the employees possibility of an extended working life, i.e. there was no statistically significant association between the managers' attitudes towards the employees abilities and the competence measures to increase employees' participation in an extended working life. 
One strength of this study was the possibility to examine differences between determinant areas and whether mangers believe their employees can and want to extend their working life beyond 65 years of age. All nine areas in the analysis is in the swAge-model and has been identified in previous studies as very important to retirement and retirement planning $(1,7-36)$, but all areas has not been included in the same study about managers' attitude towards their employees possibility of working in an extended working life before. Furthermore, to the best of our knowledge, previous studies has made no distinction between whether managers believe their employees 'can' or 'want to' work in an extended working life.

\section{Conclusion}

Work is an important part of an individuals' life. The demographic change in most societies affects human resources planning and working life in the future. The attitude of managers toward employees' situations and abilities is of great importance in the employee's decision to extend or withdraw from working life. The results in this study show that health, physical work environment, skills and competence were particularly important areas to whether managers believe that their employees can work until 65 years of age or beyond. Measures at the workplace to increase the employee's opportunity of being able to work in an extended working life were decrease of demands, more rotation between different tasks to reduce work load and wear and to offer other tasks in the workplace if needed. The results also stated that the social work environment, whether the employees received enough support from the managers, and the possibility of arranging relocation if the employees experienced that the work environment was too demanding for them, were the most important to whether the managers believe that their employees want to work until age 65 or beyond. Measures in the workplace to increase the opportunity of employees wanting to work in an extended working life were decrease of work pace, reduction of working hours (i.e. increased leisure time between shifts) and to offer the employee other tasks in the workplace if needed. Actually, measures to offer the employee other tasks in the workplace if needed was both important to whether the managers believed their employees could and want to go on and work in extended working life. However, if that is a realistic measure in a workplace and an organisation is not possible to state in this study.

The result from this study regarding managers' perspectives on whether their employees 'can' and 'want' to work until an older age will hopefully make a contribution to the understanding of the extended working life process. The results also proves a robustness of the determinant areas of knowledge in the swAge-model. Additionally, the study's contribution to the knowledge regarding measures for an extended working life can hopefully also be important in workplace intervention planning and future research for a sustainable working life until an older age.

\section{Abbreviations}

$\mathrm{Cl}$ 
confidence interval

OR

odds ratio

$P$

probability value

swAge

Sustaniable working life for all ages

\section{Declarations}

Ethics approval and consent to participate: The study was conducted according to the ethical codes and principles expressed in the Declaration of Helsinki, and was approved by The Regional Ethical Review Board in Lund (no 2018/27). Consent to participate was collected from the participants in the survey.

Consent to publish: Consent for publication of the result was collected from the participants in the survey.

Availability of data and materials: The datasets analysed during the current study available from the corresponding author on reasonable request.

Competing interests: The authors declare that they have no competing interests

Funding: The study was funded by AFA insurance

Authors' Contributions: KN performed the survey and analysed the data. EN and KN writing the manuscript. All authors read and approved the final manuscript.

Acknowledgement: A great Thank you! to HR manager Kristina Trulsson Samuelsson for her help to carrying through the study. We also want to thanks the AFA insurance, who funded this research.

\section{References}

1. Nilsson K. A sustainable working life for all ages - The swAge-model. Applied Ergonomics 2020; 103082: 1-27. https://www.sciencedirect.com/science/article/pii/S0003687018305313? dgcid=author [cited 3 April 2020]

2. Ilmarinen J. Toward a longer working life: Aging and quality of working life in the European Union. Helsinki: Finnish Institute of Occupational Health; 2006.

3. OECD. Pensions at a Glance 2017: OECD and G20 Indicators. Paris: OECD Publishing, 2017. http://dx.doi.org/10.1787/pension_glance-2017-en [cited 18 Mach 2020]

4. Eurostat. Active ageing and solidarity between generations - a statistical portrait of the European Union 2012. Luxembourg: Publications Office of the European Union; 2011.

5. European Commission. Demography report. Luxembourg: Publications Office of the European Union; 2015. (Short analytical web note; 3/2015).

Page 14/31 
6. Hess M. Rising preferred retirement age in Europe: are Europe's future pensioners adapting to pension system reforms? J Aging Soc Policy. 2017;29(3):245-261. doi:10.1080/08959420.2016.1255082

7. Nilsson K. Rignell-Hydbom A. Rylander L. Factors influencing the decision to extend working life or to retire. Scandinavian Journal of Work, Environment and Health. 2011;37(6):473-480.

8. Nilsson K. Conceptualization of ageing in relation to factors of importance for extending working life - a review. Scandinavian Journal of Public Health. 2016; 44: 490-505.

9. Nilsson K. The Influence of Work Environmental and Motivation Factors on Seniors' Attitudes to an Extended Working Life or to Retire. A Cross Sectional Study with Employees 55 - 74 Years of Age. Open Journal of Social Sciences 2017;5:30-41.

10. Pietiläinen O. Laaksonen M. Rahkonen O. Lahelma E. Self-rated Health as a Predictor of Disablility Retirement - The Contribution of III-Health and Working Conditions. PLoS ONE. 2011;6(9):e25004. doi:10.1371/journal.pone0025004.

11. Nilsson K. Rignell-Hydbom A. Rylander L. How is self-rated health and diagnosed disease associate with early or deferred retirement: a cross sectional study with employees aged 55-64. BMC Public Health. 2016:886. Doi:10.1186/s12889-016-3438-6

12. Börsch-Supan A. Brugiavini A. Croda E. The role of institutions and health in European patterns of work and retirement. Journal of European Social Policy. 2009;19:341-358.

13. Karlsson NE. Carstens JM. Gjesdal S. Alexandersson KAE. Work and Health. Risk factors for disability pension in a population-based cohort of men and women on long-term sick leave in Sweden. European Journal of Public Health. 2008;18(3):224-231.

14. Sauré P. Zoabi H. Retirement age across countries: The role of occupations, Swiss National Bank Working Papers 6/2012, Zurich, 2011. http://papers.ssrn.com/sol3/papers.cfm? abstract_id=1940452 (cited 10 March 2020)

15. von Bonsdorff M.E. Rantanen T. Törmäkangas T. Kulmala J. Hinrichs T. Seitsamo J. von Bonsdorff M.B. Midlife work ability and mobility limitation in old age among non-disability and disability retirees: A prospective study. BMC Public Health. 2016;16(1), 154-161. doi:10.1186/s12889-0162846-y

16. Kunze F. Reas AML. It Matter How Old You Feel: Antecedents and Performance Consequences of Average Relative Subjective Age in Organizations. J. of Applied Psychology 2015;100(5):1511-1526.

17. Hovbrandt P. Carlsson G. Nilsson K. Albin M. Håkansson C. Occupational balance as described by older workers over the age of 65. Journal of Occupational Science. 2019;26(1):40-52. doi:10.1080/14427591.2018.1542616

18. Canivet C. Choi BK. Karasek R. Moghaddassi M. Staland-Nyman C. Östergren P-O. Can high psychological job demands, low decision latitude, and high job strain predict disability pensions? A 12-year follow-up of middle-aged Swedish workers. International Archive Occupational Environmental Health. 2013;86(3):307-19. doi:10.1007/s00420-012-0766-4. 
19. Mykletun R. Furunes T. The Ageing Workforce Management Programme in Vatenfall AB Nordic, Sweden. In Ennals R. Salomon RH. (eds.) Older Workers in a Sustainable Society. Labor, Education \& Society: Frankfurt: Peter Lang Verlag, 2011: 93-106.

20. Furunes T Mykletun R. Managers' Decision Latitude for Age Management: Do Managers and Employees have the same (implicit) Understanding? In Ennals R. Salomon RH. (eds.) Older Workers in a Sustainable Society. Labor, Education \& Society: Frankfurt, Peter Lang Verlag; 2011. p.107-116.

21. Laaksonen M. Metsä-Simola N. Martikainen P. Pietiläinen O. Rahkonen O. Gould R. Partonen T. Lahelma E. Trajectories of mental health before and after old-age and disability retirement: a registerbased study on purchases of psychotropic drugs. Scandinavian Journal of Work, Environment \& Health. 2012;38(5):409-417. doi:org/10.5271/sjweh.3290.

22. Cobb-Clark DA. Stillman S. The Retirement Expectations of Middle-aged Australians. The Economic Record. 2009;85(269):146-163. doi:10.1111/j.1475-4932.2009.00543.x.

23. Brenes-Comacho G. Favourable changes in economic well-being and self-rated health among the elderly. Social Science \& Medicine. 2011;72(8-10):1228-1235.

24. Nilsson K. Östergren P-O. Kadefors R. Albin M. Has the participation of older employees in the workforce increased? Study of the total Swedish population regarding exit working life. Scandinavian Journal of Public Health. 2016;44: 506-516.

25. Hanson Frieze I. Olson JE. Murrell AJ. Working Beyond 65: Predictors of Late Retirement for Women and Men MBAs. Journal of Women \& Aging. 2011;23:40-57.

26. Gyllensten K. Wentz K. Håkansson C. Nilsson K. Older assistant nurses' motivation for a full or extended working life. Ageing \& Society. 2019;39(12): 2699-2713.

27. Friis K. Ekholm O. Hundrup YA. Obel EB. Grønbaek M. Influence of health, lifestyle, working conditions, and sociodemography on early retirement among nurses: The Danish Nurse Cohort Study. Scandinavian Journal of Public Health. 2007; 35:23-30.28.

28. Jensen PH. Juul Møberg R. Age Management in Danish Companies: What, How and How Much? Nordic Journal of Working Life Studies. 2012; 2(3):49-65.

29. Nilsson K. Managers' attitudes to their older employees - a cross-sectional study. WORK: A Journal of Prevention, Assessment and Rehabilitation. 2018;59(1):49-58.

30. Cheung F. Wu AMS. An investigation of predictors of successful aging in the workplace among Hong Kong Chinese older workers. International Psychogeriatrics. 2012. 24(3):449-464.

31. Jokela M. Ferrie JE. Gimeno D. Chandola T. Shipley MJ. Head J. Vahtera J. Westerlund H. Marmot MG. Kivimäki M. From Midlife to early Old Age. Health trajectories Associated With Retirement. Epidemiology 2010; 21(3):284-290.

32. Oude Hengel K. Blatter BM. van der Molen HF. Bongers PM. van der Beek AJ. The effectiveness of a construction worksite prevention program on work ability, health, and sick leave: results from a cluster randomized controlled trial. Scand J Work Environ Health. 2013;39(5):456-467. doi: $10.5271 /$ sjweh.3361 
33. Hovbrandt C. Håkansson C. Karlsson G. Albin M. Nilsson K. Prerequisites and driving forces behind an extended working life among older workers. Scandinavian Journal of Occupational Therapy. 2017; Nov.28:1-13. doi:10.1080/11038128.2017.1409800.

34. Mather M. Aging and cognition. Cognitive Science. 2010.;1:346-362.

35. Backes-Gellner U. Schneider MR. Veen S. Effect of Workforce Age on Quantitative and Qualitative Organizational Performance: Conceptual Framwork and Case Study Evidence. Organisational Studies. 2011;32(8):1103-1121.

36. Doyle YG. McKee M. Sherriff M. A model of successful ageing in British populations. European Journal of Public Health. 2012; 22(1):77-76.

37. Forma P. Tuominen E. Väänänen-Tomppo I. Who wants to continue at work? Finnish pension reform and the future plans of older workers. European Journal of Social Security. 2005;7:227-250.

38. Umegård B. Sveriges viktigaste jobb finns i välfärden [Sweden's most important job is in welfare]. Stockholm: Swedish Association of Local Authorities and Regions; 2018:1-52. (in Swedish).

39. Li C-Y, Sung F-C. A review of the healthy worker effect in occupational epidemiology. Occupational Medicine. 1999; 49: 225-229.

40. Nilsson K. Chefers attityder till äldre medarbetare inom kommunen. [Municipal managers attitude to their older workers] Stockholm: Swedish National Institute of Working life, 2007;4:1-30. (in Swedish)

41. Löfgren L. Nilsson K. Chefer - Hållbart arbetsliv i Helsingborgs stad. [Managers - Sustainable working life in the city of Helsingborg ] Lund: Division of Occupational and Environmental Medicine Lund University. 2019;17:1-72. (in Swedish)

42. McGoldrick AE. Arrowsmith J. Discrimination by age: the organizational response. In Glover I. \& Branine M. (eds.) Ageism in Work and Employment: 2001:75-96. Stirling: Ashgate Publishing Ltd.

43. Karasek R. Theorell T. Healthy work: Stress, productivity, and the Reconstruction of working life. New York: Basic books, 1990.

\section{Tables}

Table 1. Proportion (\%) of respondents who believe their employees can work until the age of 55-60; 61-62; 63-64; 65; 66-67; 68-69; 70 years of age or beyond.

\begin{tabular}{|l|l|l|l|l|l|l|}
\hline \multicolumn{6}{|c|}{ Age (years) to which respondents believe their employees can work } \\
\hline $55-60$ & $61-62$ & $63-64$ & 65 & $66-67$ & $68-69$ & $\geq 70$ \\
\hline $2,0 \%$ & $8,4 \%$ & $12,0 \%$ & $32,5 \%$ & $34,5 \%$ & $6,4 \%$ & $4,0 \%$ \\
\hline
\end{tabular}

Table 2. Proportion (\%) of respondents who believe their employees want to work until the age of 55-60; 61-62; 63-64; 65; 66-67; 68-69; 70 years of age or beyond. 


\begin{tabular}{|l|l|l|l|l|l|l|}
\hline \multicolumn{6}{|c|}{ Age (years) to which respondents believe their employees can work } \\
\hline $55-60$ & $61-62$ & $63-64$ & 65 & $66-67$ & $68-69$ & $\geq 70$ \\
\hline $5,6 \%$ & $12,0 \%$ & $24,1 \%$ & $30,9 \%$ & $24,9 \%$ & $1,6 \%$ & $0,8 \%$ \\
\hline
\end{tabular}

Table 3. Distributions regarding whether the manager believe their employees' 'can work' outcome for the statements included in the univariate and final multivariate model in the determinant areas, and the corresponding odds ratios (OR), significant value (P) and 95\% confidence intervals (CI) obtained from logistic regression. ORs indicate the statements relation to the managers' belief whether their employees' can work until 65 years of age or beyond. 


\begin{tabular}{|c|c|c|c|c|c|c|c|c|}
\hline \multirow[t]{2}{*}{$\begin{array}{l}\text { Determinant } \\
\text { sphere }\end{array}$} & \multirow[t]{2}{*}{ Determinant areas } & \multirow[t]{2}{*}{ Statement } & \multicolumn{3}{|c|}{ Univariate estimates } & \multicolumn{3}{|c|}{$\begin{array}{l}\text { Multivariate model of can } \\
\text { work } \geq 65 \text { in the } \\
\text { determent area }\end{array}$} \\
\hline & & & OR & $\mathrm{P}$ & $\begin{array}{l}95 \% \\
\text { CI }\end{array}$ & OR & $\mathrm{P}$ & $\begin{array}{l}95 \% \\
\text { CI }\end{array}$ \\
\hline \multirow[t]{14}{*}{$\begin{array}{l}\text { The work } \\
\text { environments } \\
\text { health effect }\end{array}$} & \multirow[t]{2}{*}{$\begin{array}{l}\text { Health, diagnoses, } \\
\text { function variations }\end{array}$} & $\begin{array}{l}\text { The majority of my employees do not } \\
\text { seem to experience well-being in their } \\
\text { daily life }\end{array}$ & 4.381 & $0.006 *$ & $\begin{array}{l}1.51- \\
12.68\end{array}$ & 4.238 & $0.009 *$ & $\begin{array}{l}1.43- \\
12.57\end{array}$ \\
\hline & & $\begin{array}{l}\text { The majority of my employees have } \\
\text { some kind of diagnosis or chronic } \\
\text { disease }\end{array}$ & 3.035 & $0.005^{*}$ & $\begin{array}{l}1.41- \\
6.54\end{array}$ & 3.126 & $0.005^{*}$ & $\begin{array}{l}1.42- \\
6.89\end{array}$ \\
\hline & \multirow[t]{6}{*}{$\begin{array}{l}\text { Physical work } \\
\text { environment }\end{array}$} & $\begin{array}{l}\text { I experience that my employees in } \\
\text { general have many tasks involving a } \\
\text { physically demanding work load and } \\
\text { heavy lifting }\end{array}$ & 7.014 & $<0.001 *$ & $\begin{array}{l}3.05- \\
16.15\end{array}$ & 5.366 & $<0.001 * *$ & $\begin{array}{l}2.239- \\
12.860\end{array}$ \\
\hline & & $\begin{array}{l}\text { I do not experience that my employees } \\
\text { have a reasonable physical work load }\end{array}$ & 7.130 & $<0.001 *$ & $\begin{array}{l}2.65- \\
19.16\end{array}$ & 4.719 & $0.004^{*}$ & $\begin{array}{l}1.632- \\
13.644\end{array}$ \\
\hline & & $\begin{array}{l}\text { I experience that my employees in } \\
\text { general run the risk of occupational } \\
\text { injury and occupational disease based } \\
\text { on the physical work environment }\end{array}$ & 4.332 & $0.004^{*}$ & $\begin{array}{l}1.59- \\
11.84\end{array}$ & & & \\
\hline & & $\begin{array}{l}\text { I experience that my employees in } \\
\text { general have many physically } \\
\text { unilateral work tasks }\end{array}$ & 2.090 & $0.049 *$ & $\begin{array}{l}1.00- \\
4.35\end{array}$ & & & \\
\hline & & $\begin{array}{l}\text { I do not experience that there is } \\
\text { sufficient ergonomic support and aids } \\
\text { for my employees work }\end{array}$ & 1.632 & 0.341 & $\begin{array}{l}0.60- \\
4.48\end{array}$ & & & \\
\hline & & $\begin{array}{l}\text { I do not experience that my employees } \\
\text { in general are good at using ergonomic } \\
\text { support and aids }\end{array}$ & 1.063 & 0.87 & $\begin{array}{l}0.51- \\
2.20\end{array}$ & & & \\
\hline & \multirow[t]{5}{*}{$\begin{array}{l}\text { Mental work } \\
\text { Environment }\end{array}$} & $\begin{array}{l}\text { I do not experience that there is a } \\
\text { general balance between the demands } \\
\text { put on my employees in their work, } \\
\text { and the control they have in executing } \\
\text { their work tasks }\end{array}$ & 1.813 & 0.115 & $\begin{array}{l}0.865- \\
3.800\end{array}$ & & & \\
\hline & & $\begin{array}{l}\text { I experience that my employees run } \\
\text { the risk of being subjected to violence } \\
\text { and threats in their work }\end{array}$ & 1.368 & 0.319 & $\begin{array}{l}0.739- \\
2.535\end{array}$ & & & \\
\hline & & $\begin{array}{l}\text { I experience that my employees in } \\
\text { general run the risk of occupational } \\
\text { injury and occupational disease based } \\
\text { on the mental work environment }\end{array}$ & 1.338 & 0.404 & $\begin{array}{l}0.675- \\
2.655\end{array}$ & & & \\
\hline & & $\begin{array}{l}\text { I experience that my employees in } \\
\text { general are too stressed in their work } \\
\text { due to current circumstances in the } \\
\text { work place }\end{array}$ & 1.306 & 0.408 & $\begin{array}{l}0.694- \\
2.461\end{array}$ & & & \\
\hline & & $\begin{array}{l}\text { I experience that my employees in } \\
\text { general are too stressed in their work } \\
\text { due to political decisions and } \\
\text { circumstances in society }\end{array}$ & 1.225 & 0.507 & $\begin{array}{l}0.672- \\
2.233\end{array}$ & & & \\
\hline & Work schedule, work & I do not experience that my employees & 2.066 & 0.059 & $0.972-$ & 2.066 & 0.059 & 0.97 \\
\hline
\end{tabular}




\begin{tabular}{|c|c|c|c|c|c|c|c|c|}
\hline & \multirow[t]{4}{*}{ pace and recuperation } & $\begin{array}{l}\text { in general have sufficient opportunity } \\
\text { of taking breaks when working }\end{array}$ & & & 4.390 & & & 4.390 \\
\hline & & $\begin{array}{l}\text { I do not experience that my employees } \\
\text { in general have a good work schedule } \\
\text { that enables recuperation between } \\
\text { work shifts" }\end{array}$ & 2.003 & 0.118 & $\begin{array}{l}0.838- \\
4.784\end{array}$ & & & \\
\hline & & $\begin{array}{l}\text { I experience that it can be a problem } \\
\text { to keep the work activities running due } \\
\text { to lack of temp workers when } \\
\text { employees are off work }\end{array}$ & 1.276 & 0.431 & $\begin{array}{l}0.696- \\
2.341\end{array}$ & & & \\
\hline & & $\begin{array}{l}\text { I experience that my employees in } \\
\text { general have too many work tasks due } \\
\text { to lack of employees }\end{array}$ & 1.239 & 0.528 & $\begin{array}{l}0.636- \\
2.415\end{array}$ & & & \\
\hline Finances & Personal finances & $\begin{array}{l}\text { I experience that my employees in } \\
\text { general feel pressured by their } \\
\text { financial situation (i.e. having difficulty } \\
\text { getting by on their salary, health } \\
\text { insurance and/or other social security } \\
\text { systems) }\end{array}$ & 3.269 & $<0.001 * *$ & $\begin{array}{l}1.619- \\
6.601\end{array}$ & 3.269 & $<0.001 * *$ & $\begin{array}{l}1.619- \\
6.601\end{array}$ \\
\hline \multirow[t]{8}{*}{$\begin{array}{l}\text { Support and } \\
\text { community }\end{array}$} & \multirow[t]{2}{*}{ Privatsocialenvironment } & $\begin{array}{l}\text { I do not experience that my employees } \\
\text { in general have sufficient opportunity } \\
\text { of combining work with their leisure } \\
\text { activities and social relations in their } \\
\text { leisure time. }\end{array}$ & 2.472 & 0.062 & $\begin{array}{l}0.956- \\
6.390\end{array}$ & 2.472 & 0.062 & $\begin{array}{l}0.956- \\
6.390\end{array}$ \\
\hline & & $\begin{array}{l}\text { I do not experience that my employees } \\
\text { in general have sufficient opportunity } \\
\text { of combining work with their family } \\
\text { situation, partner, children, } \\
\text { grandchildren etc. }\end{array}$ & 1.964 & 0.205 & $\begin{array}{l}0.692- \\
5.572\end{array}$ & & & \\
\hline & $\begin{array}{l}\text { Work } \\
\text { social environment }\end{array}$ & $\begin{array}{l}\text { My employees in general do not } \\
\text { receive sufficient support from me to } \\
\text { be able to work until ordinary } \\
\text { retirement age }\end{array}$ & 5.451 & $0.005^{*}$ & $\begin{array}{l}1.656- \\
17.946\end{array}$ & 4.158 & $0.023^{*}$ & $\begin{array}{l}1.212- \\
14.268\end{array}$ \\
\hline & & $\begin{array}{l}\text { I am not satisfied with the extent of } \\
\text { support that I offer my employees for } \\
\text { them to be able to cope with their } \\
\text { work tasks }\end{array}$ & 2.415 & $0.017^{*}$ & $\begin{array}{l}1.169- \\
4.989\end{array}$ & 2.290 & $0.035^{*}$ & $\begin{array}{l}1.060- \\
4.948\end{array}$ \\
\hline & & $\begin{array}{l}\text { I do not experience that my employees } \\
\text { in general receive sufficient support to } \\
\text { be able to cope with their work tasks } \\
\text { from their co-workers, others in the } \\
\text { organization and supporting } \\
\text { organizations }\end{array}$ & 1.833 & 0.190 & $\begin{array}{l}0.740- \\
4.540\end{array}$ & & & \\
\hline & & $\begin{array}{l}\text { I am not satisfied with the quality of } \\
\text { the support that I offer my employees } \\
\text { for them to be able to cope with their } \\
\text { work tasks }\end{array}$ & 1.652 & 0.333 & $\begin{array}{l}0.598- \\
4.568\end{array}$ & & & \\
\hline & & $\begin{array}{l}\text { I experience that my elderly } \\
\text { employees are subjected to } \\
\text { discrimination/disregard by others in } \\
\text { the workplace (co-workers, patients, } \\
\text { clients etc.) }\end{array}$ & 2.115 & 0.488 & $\begin{array}{l}0.255- \\
17.569\end{array}$ & & & \\
\hline & & I do not experience that my employees & 1.150 & 0.780 & $0.433-$ & & & \\
\hline
\end{tabular}




\begin{tabular}{|c|c|c|c|c|c|c|c|c|}
\hline & & $\begin{array}{l}\text { in general have reasonable opportunity } \\
\text { of participation in decisions regarding } \\
\text { work organisation }\end{array}$ & & & 3.054 & & & \\
\hline & & $\begin{array}{l}\text { I do not experience leadership to be } \\
\text { crucial for elderly employees } \\
\text { consideration to keep working after } 65 \\
\text { years of age }\end{array}$ & 1.016 & 0.960 & $\begin{array}{l}0.558- \\
1.849\end{array}$ & & & \\
\hline \multirow[t]{12}{*}{$\begin{array}{l}\text { Execution of } \\
\text { work tasks }\end{array}$} & \multirow[t]{6}{*}{$\begin{array}{l}\text { Work tasks stimulation, } \\
\text { motivation, self- } \\
\text { crediting }\end{array}$} & $\begin{array}{l}\text { I do not experience it being possible to } \\
\text { adjust work tasks to elderly employees } \\
\text { in my organization }\end{array}$ & 3.900 & $<0.001 * *$ & $\begin{array}{l}2.053- \\
7.408\end{array}$ & 3.900 & $<0.001 * *$ & $\begin{array}{l}2.053- \\
7.408\end{array}$ \\
\hline & & $\begin{array}{l}\text { In my experience it is hard to find } \\
\text { work tasks to relocate employees who } \\
\text { experience their work environment as } \\
\text { too physically demanding }\end{array}$ & 2.621 & $0.004^{*}$ & $\begin{array}{l}1.36- \\
5.05\end{array}$ & & & \\
\hline & & $\begin{array}{l}\text { In my experience it is hard to find } \\
\text { work tasks to relocate employees who } \\
\text { experience their work environment as } \\
\text { too mentally demanding }\end{array}$ & 2.230 & 0.030 & $\begin{array}{l}1.081- \\
4.600\end{array}$ & & & \\
\hline & & $\begin{array}{l}\text { I do not experience that my employees } \\
\text { in general have reasonable opportunity } \\
\text { of participation in decisions regarding } \\
\text { their work tasks }\end{array}$ & 3.720 & 0.070 & $\begin{array}{l}0.899- \\
15.400\end{array}$ & & & \\
\hline & & $\begin{array}{l}\text { I do not experience that my employees } \\
\text { in general are satisfied in their daily } \\
\text { work }\end{array}$ & 2.400 & 0.086 & $\begin{array}{l}0.883- \\
6.520\end{array}$ & & & \\
\hline & & $\begin{array}{l}\text { I do not experience that my employees } \\
\text { in general have work tasks that they } \\
\text { experience as stimulating and } \\
\text { meaningful }\end{array}$ & 2.302 & 0.368 & $\begin{array}{l}0.375- \\
14.138\end{array}$ & & & \\
\hline & \multirow[t]{6}{*}{ Knowledge, competence } & $\begin{array}{l}\text { I do not experience that my employees } \\
\text { have access to sufficient technical } \\
\text { support }\end{array}$ & 3.468 & $0.003^{*}$ & $\begin{array}{l}1.547- \\
7.772\end{array}$ & 3.539 & $0.003^{*}$ & $\begin{array}{l}1.557- \\
8.043\end{array}$ \\
\hline & & $\begin{array}{l}\text { I do not experience it being important } \\
\text { to keep elderly employees in the } \\
\text { organization based on their } \\
\text { competence }\end{array}$ & 2.322 & $0.022^{*}$ & $\begin{array}{l}1.128- \\
4.778\end{array}$ & 2.497 & 0.016 & $\begin{array}{l}1.188- \\
5.25\end{array}$ \\
\hline & & $\begin{array}{l}\text { I do not experience that my elderly } \\
\text { employees have the right knowledge } \\
\text { and experience for their work tasks }\end{array}$ & 2.536 & $0.035^{*}$ & $\begin{array}{l}1.069- \\
6.015\end{array}$ & & & \\
\hline & & $\begin{array}{l}\text { I do not experience that my elderly } \\
\text { employees in general have opportunity } \\
\text { of continuous competence } \\
\text { development }\end{array}$ & 2.131 & 0.132 & $\begin{array}{l}0.796- \\
5.702\end{array}$ & & & \\
\hline & & $\begin{array}{l}\text { I do not experience that my elderly } \\
\text { employees in general have the } \\
\text { knowledge and experience that enable } \\
\text { them to find a job in the eventuality of } \\
\text { re-organization and changes }\end{array}$ & 1.469 & 0.220 & $\begin{array}{l}0.795- \\
2.713\end{array}$ & & & \\
\hline & & I do not experience that my employees & 1.741 & 0.653 & $0.155-$ & & & \\
\hline
\end{tabular}

Page 21/31 


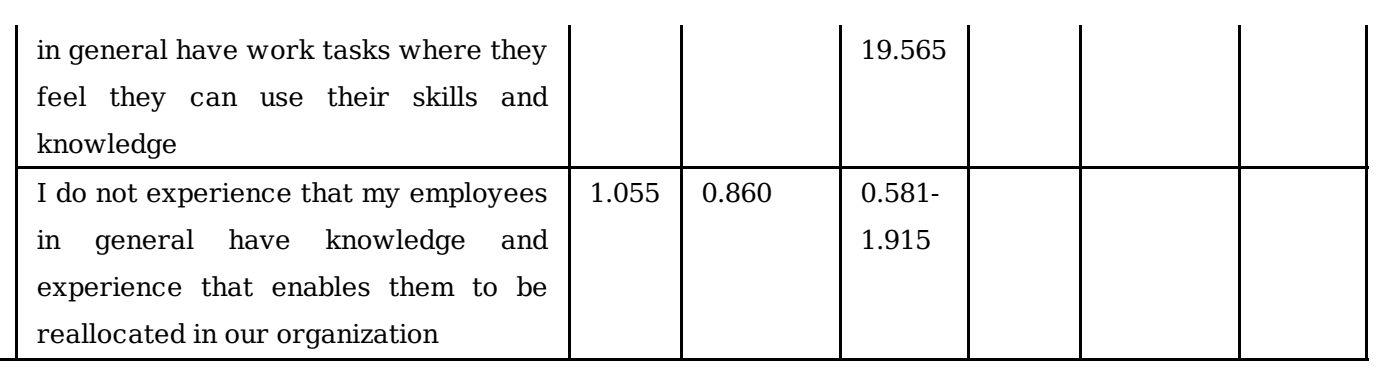

Table 4. The final multivariate model distributions regarding all the determinant areas combined and whether the manager believe their employees' 'can work' outcome for the statements. The corresponding odds ratios (OR), significant value (P) and 95\% confidence intervals (CI) obtained from logistic regression. ORs in the multivariate model indicate the statements' relation to the managers' belief whether their employees' can work until 65 years of age or beyond.

\begin{tabular}{|c|c|c|c|c|c|}
\hline \multirow[t]{2}{*}{$\begin{array}{l}\text { Determinant } \\
\text { sphere }\end{array}$} & \multirow[t]{2}{*}{ Determinant areas } & \multirow[t]{2}{*}{ Statement } & \multicolumn{3}{|c|}{$\begin{array}{l}\text { Multivariate model in } \\
\text { the determent area }\end{array}$} \\
\hline & & & OR & $\mathrm{P}$ & $\begin{array}{l}95 \% \\
\text { CI }\end{array}$ \\
\hline \multirow{5}{*}{$\begin{array}{l}\text { The work } \\
\text { environments } \\
\text { health effect }\end{array}$} & $\begin{array}{l}\text { Health, diagnoses, } \\
\text { function variations }\end{array}$ & $\begin{array}{l}\text { The majority of my employees have some kind of diagnosis or } \\
\text { chronic disease }\end{array}$ & 2.725 & $0.033^{*}$ & $\begin{array}{l}1.086- \\
6.841\end{array}$ \\
\hline & \multirow[t]{2}{*}{$\begin{array}{l}\text { Physical work } \\
\text { environment }\end{array}$} & $\begin{array}{l}\text { I experience that my employees in general have many tasks } \\
\text { involving a physically demanding work load and heavy lifting }\end{array}$ & 4.660 & $0.002 *$ & $\begin{array}{l}1.779- \\
12.209\end{array}$ \\
\hline & & $\begin{array}{l}\text { I do not experience that my employees have a reasonable } \\
\text { physical work load }\end{array}$ & 4.832 & $0.008 *$ & $\begin{array}{l}1.526- \\
15.361\end{array}$ \\
\hline & $\begin{array}{l}\text { Mental work } \\
\text { environment }\end{array}$ & - & & & \\
\hline & $\begin{array}{l}\text { Work schedule, work } \\
\text { pace and recovery }\end{array}$ & - & & & \\
\hline Finances & Personal finances & - & & & \\
\hline \multirow[t]{2}{*}{$\begin{array}{l}\text { Support and } \\
\text { community }\end{array}$} & $\begin{array}{l}\text { Private social } \\
\text { environment }\end{array}$ & - & & & \\
\hline & Work social environment & - & & & \\
\hline \multirow[t]{3}{*}{$\begin{array}{l}\text { Execution of work } \\
\text { tasks }\end{array}$} & $\begin{array}{l}\text { Work tasks stimulation, } \\
\text { motivation, self-crediting }\end{array}$ & - & & & \\
\hline & \multirow[t]{2}{*}{$\begin{array}{l}\text { Competence, skills, } \\
\text { knowledge development }\end{array}$} & $\begin{array}{l}\text { I do not experience that my employees have access to sufficient } \\
\text { technical support }\end{array}$ & 2.834 & $0.030 *$ & $\begin{array}{l}1.109- \\
7.244\end{array}$ \\
\hline & & $\begin{array}{l}\text { I do not experience it being important to keep elderly employees } \\
\text { in the organization based on their competence }\end{array}$ & 3.572 & $0.002 *$ & $\begin{array}{l}1.603- \\
7960\end{array}$ \\
\hline
\end{tabular}


Table 5. Measure statements associated to whether the manager believe their employees' "can work" outcome for the statements. The corresponding odds ratios (OR), significant value $(\mathrm{P})$ and 95\% confidence intervals $(\mathrm{CI})$ obtained from logistic regression. ORs in the univariate estimates indicate different measures in relation to the managers' belief that their employees' can work until 65 years of age or beyond. 


\begin{tabular}{|c|c|c|c|c|c|}
\hline $\begin{array}{l}\text { Determinant } \\
\text { sphere }\end{array}$ & Determinant areas & $\begin{array}{l}\text { Measures to increase employees' ability to work until } 65 \text { years of age } \\
\text { or longer }\end{array}$ & OR & $\mathrm{P}$ & $\begin{array}{l}95 \% \\
\text { CI }\end{array}$ \\
\hline \multirow{11}{*}{$\begin{array}{l}\text { The work } \\
\text { environments } \\
\text { health effect }\end{array}$} & $\begin{array}{l}\text { Health, diagnoses, } \\
\text { function variations }\end{array}$ & $\begin{array}{l}\text { Compulsory exercise/health care to keep employees in mental and } \\
\text { physical shape until an older age }\end{array}$ & 1.190 & 0.567 & $\begin{array}{l}0.656- \\
2.161\end{array}$ \\
\hline & \multirow[t]{2}{*}{$\begin{array}{l}\text { Physical work } \\
\text { environment }\end{array}$} & Decrease of physical work demands & 2.885 & $0.001 * *$ & $\begin{array}{l}1.568- \\
5.310\end{array}$ \\
\hline & & $\begin{array}{l}\text { Rotation between different work tasks to decrease physical work } \\
\text { load and strain }\end{array}$ & 2.128 & 0.019 & $\begin{array}{l}1.132- \\
4.002\end{array}$ \\
\hline & \multirow[t]{3}{*}{$\begin{array}{l}\text { Mental work } \\
\text { environment }\end{array}$} & $\begin{array}{l}\text { Rotation between different work tasks to decrease mental work load } \\
\text { and strain }\end{array}$ & 1.881 & 0.040 & $\begin{array}{l}1.030- \\
3.433\end{array}$ \\
\hline & & Decrease of mental work demands & 1.823 & $0.051 *$ & $\begin{array}{l}0.997- \\
3.333\end{array}$ \\
\hline & & Increased self-monitoring of work & 1.355 & 0.322 & $\begin{array}{l}0.742- \\
2.475\end{array}$ \\
\hline & \multirow[t]{5}{*}{$\begin{array}{l}\text { Work schedule, work } \\
\text { pace and recuperation }\end{array}$} & Change in the organization of work hours & 1.806 & 0.069 & $\begin{array}{l}0.955- \\
3.412\end{array}$ \\
\hline & & Increased time for recuperation between work shifts & 1.755 & 0.071 & $\begin{array}{l}0.952- \\
3.231\end{array}$ \\
\hline & & Shorter working hours & 1.952 & 0.188 & $\begin{array}{l}0.721- \\
5.282\end{array}$ \\
\hline & & Being able to take breaks when needed & 1.302 & 0.402 & $\begin{array}{l}17.02- \\
2.412\end{array}$ \\
\hline & & Decrease of work pace & 1.106 & 0.772 & $\begin{array}{l}0.559- \\
2.191\end{array}$ \\
\hline \multirow[t]{2}{*}{ Economics } & \multirow[t]{2}{*}{ Personal finances } & Higher salary & 1.050 & 0.881 & $\begin{array}{l}0.555- \\
1.988\end{array}$ \\
\hline & & Decreased pension to keep employees from retiring too early & 1.372 & 0.404 & $\begin{array}{l}0.653- \\
2.883\end{array}$ \\
\hline \multirow[t]{3}{*}{$\begin{array}{l}\text { Support and } \\
\text { community }\end{array}$} & $\begin{array}{l}\text { Private social } \\
\text { environment }\end{array}$ & - & & & \\
\hline & \multirow[t]{2}{*}{$\begin{array}{l}\text { Work social } \\
\text { environment }\end{array}$} & Increased participation in work & 1.233 & 0.497 & $\begin{array}{l}0.674- \\
2.255\end{array}$ \\
\hline & & Increased well-being and unity & 1.174 & 0.615 & $\begin{array}{l}0.629- \\
2.192\end{array}$ \\
\hline \multirow[t]{6}{*}{$\begin{array}{l}\text { Execution of } \\
\text { work tasks }\end{array}$} & \multirow{6}{*}{$\begin{array}{l}\text { Work tasks } \\
\text { stimulation, } \\
\text { motivation, self- } \\
\text { crediting }\end{array}$} & Other work tasks in the work place when needed & 2.230 & $0.015^{*}$ & $\begin{array}{l}1.170- \\
4.251\end{array}$ \\
\hline & & Increased opportunity of development at work & 1.584 & 0.132 & $\begin{array}{l}0.871- \\
2.879\end{array}$ \\
\hline & & Increased work satisfaction & 1.583 & 0.144 & $\begin{array}{l}0.857- \\
2.925\end{array}$ \\
\hline & & $\begin{array}{l}\text { Increased opportunity of changing occupation and career at an older } \\
\text { age }\end{array}$ & 1.242 & 0.480 & $\begin{array}{l}0.681- \\
2.264\end{array}$ \\
\hline & & $\begin{array}{l}\text { That employees in increased extent can focus on work tasks that they } \\
\text { themselves experience as being the most important and interesting in } \\
\text { their work }\end{array}$ & 1.224 & 0.508 & $\begin{array}{l}0.673- \\
2.227\end{array}$ \\
\hline & & New job within their occupational area & 1.157 & 0.683 & $\begin{array}{l}0.575- \\
2.327\end{array}$ \\
\hline
\end{tabular}




\begin{tabular}{|c|c|c|c|c|}
\hline & Increased career opportunities & 1.133 & 0.695 & $\begin{array}{l}0.606- \\
2.119\end{array}$ \\
\hline & $\begin{array}{l}\text { Rotation between different work tasks and activities to increase } \\
\text { stimulation }\end{array}$ & 1.097 & 0.766 & $\begin{array}{l}0.598- \\
2.010\end{array}$ \\
\hline \multirow{3}{*}{$\begin{array}{l}\text { Competence, skills, } \\
\text { knowledge } \\
\text { development }\end{array}$} & Through, for the work place, need-oriented competence development & 1.190 & 0.571 & $\begin{array}{l}0.653- \\
2.167\end{array}$ \\
\hline & Through, for the employee, need-oriented competence development & 1.130 & 0.690 & $\begin{array}{l}0.621- \\
2.054\end{array}$ \\
\hline & Opportunity of new knowledge & 1.025 & 0.936 & $\begin{array}{l}0.563- \\
1.864\end{array}$ \\
\hline
\end{tabular}

Table 6. Distributions regarding whether the manager believe their employees' 'want to work' outcome for the statements included in the univariate and final multivariate model of the determinant areas, and the corresponding odds ratios (OR), significant value (P) and 95\% confidence intervals (CI) obtained from logistic regression. ORs indicate the statements' relation to whether the managers believe their employees' can work until 65 years of age or beyond. 


\begin{tabular}{|c|c|c|c|c|c|c|c|c|}
\hline \multirow[t]{2}{*}{$\begin{array}{l}\text { Determinant } \\
\text { sphere }\end{array}$} & \multirow[t]{2}{*}{$\begin{array}{l}\text { Determinant } \\
\text { areas }\end{array}$} & \multirow[t]{2}{*}{ Statement } & \multicolumn{3}{|c|}{ Univariate estimates } & \multicolumn{3}{|c|}{$\begin{array}{l}\text { Multivariate model of } \\
\text { can work } \geq 65 \text { in the } \\
\text { determent area }\end{array}$} \\
\hline & & & OR & $\mathrm{P}$ & $\begin{array}{l}95 \% \\
\text { CI }\end{array}$ & OR & $\mathrm{P}$ & $\begin{array}{l}95 \% \\
\text { CI }\end{array}$ \\
\hline \multirow[t]{15}{*}{$\begin{array}{l}\text { The work } \\
\text { environments } \\
\text { health effect }\end{array}$} & \multirow{2}{*}{$\begin{array}{l}\text { Health, } \\
\text { diagnoses, } \\
\text { function } \\
\text { variations }\end{array}$} & $\begin{array}{l}\text { The majority of my employees seem to experience } \\
\text { well-being in their daily life }\end{array}$ & 2.989 & 0.052 & $\begin{array}{l}0.990- \\
9.027\end{array}$ & 2.989 & 0.052 & $\begin{array}{l}0.990- \\
9.027\end{array}$ \\
\hline & & $\begin{array}{l}\text { The majority of my employees have some kind of } \\
\text { diagnosis or chronic disease }\end{array}$ & 1.563 & 0.234 & $\begin{array}{l}0.750- \\
3.260\end{array}$ & & & \\
\hline & \multirow[t]{6}{*}{$\begin{array}{l}\text { Physical work } \\
\text { environment }\end{array}$} & $\begin{array}{l}\text { I experience that my employees in general run the } \\
\text { risk of occupational injury and occupational disease } \\
\text { based on the physical work environment }\end{array}$ & 2.661 & 0.062 & $\begin{array}{l}0.951- \\
7.448\end{array}$ & & & \\
\hline & & $\begin{array}{l}\text { I experience that my employees in general have } \\
\text { many tasks involving a physically demanding work } \\
\text { load and heavy lifting }\end{array}$ & 1.744 & 0.168 & $\begin{array}{l}0.791- \\
3.847\end{array}$ & & & \\
\hline & & $\begin{array}{l}\text { I do not experience that my employees in general } \\
\text { have a reasonable physical work load }\end{array}$ & 1.601 & 0.326 & $\begin{array}{l}0.626- \\
4.093\end{array}$ & & & \\
\hline & & $\begin{array}{l}\text { I do not experience that my employees in general } \\
\text { are good at using ergonomic support and aids }\end{array}$ & 1.289 & 0.422 & $\begin{array}{l}0.694- \\
2.394\end{array}$ & & & \\
\hline & & $\begin{array}{l}\text { I experience that my employees in general have } \\
\text { many physically unilateral work tasks }\end{array}$ & 1.303 & 0.445 & $\begin{array}{l}0.660- \\
2.573\end{array}$ & & & \\
\hline & & $\begin{array}{l}\text { I do not experience that there is sufficient } \\
\text { ergonomic support and aids for my employees work }\end{array}$ & 1.192 & 0.709 & $\begin{array}{l}0.475- \\
2.990\end{array}$ & & & \\
\hline & \multirow[t]{5}{*}{$\begin{array}{l}\text { Mental work } \\
\text { environment }\end{array}$} & $\begin{array}{l}\text { I do not experience that there is a general balance } \\
\text { between the demands put on my employees in their } \\
\text { work, and the control they have in executing their } \\
\text { work tasks }\end{array}$ & 2.054 & 0.037 & $\begin{array}{l}1.043- \\
4.045\end{array}$ & 2.054 & 0.037 & $\begin{array}{l}1.043- \\
4.045\end{array}$ \\
\hline & & $\begin{array}{l}\text { I experience that my employees in general are too } \\
\text { stressed in their work due to political decisions and } \\
\text { circumstances in society }\end{array}$ & 1.601 & 0.070 & $\begin{array}{l}0.963- \\
2.664\end{array}$ & & & \\
\hline & & $\begin{array}{l}\text { I experience that my employees in general run the } \\
\text { risk of occupational injury and occupational disease } \\
\text { based on the mental work environment }\end{array}$ & 1.698 & 0.083 & $\begin{array}{l}0.932- \\
3.093\end{array}$ & & & \\
\hline & & $\begin{array}{l}\text { I experience that my employees in general are too } \\
\text { stressed in their work due to current circumstances } \\
\text { in the work place }\end{array}$ & 1.362 & 0.245 & $\begin{array}{l}0.809- \\
2.291\end{array}$ & & & \\
\hline & & $\begin{array}{l}\text { I experience that my employees run the risk of being } \\
\text { subjected to violence and threats in their work }\end{array}$ & 1.112 & 0.699 & $\begin{array}{l}0.649- \\
1.905\end{array}$ & & & \\
\hline & \multirow{2}{*}{$\begin{array}{l}\text { Work } \\
\text { schedule, } \\
\text { work pace and } \\
\text { recuperation }\end{array}$} & $\begin{array}{l}\text { I do not experience that my employees in general } \\
\text { have sufficient opportunity of taking breaks when } \\
\text { working }\end{array}$ & 2.376 & 0.017 & $\begin{array}{l}1.164- \\
4.851\end{array}$ & 2.376 & 0.017 & $\begin{array}{l}1.164- \\
4.851\end{array}$ \\
\hline & & $\begin{array}{l}\text { I do not experience that my employees in general } \\
\text { have a good work schedule that enables } \\
\text { recuperation between work shifts }\end{array}$ & 2.493 & 0.032 & $\begin{array}{l}1.081- \\
5.747\end{array}$ & & & \\
\hline
\end{tabular}




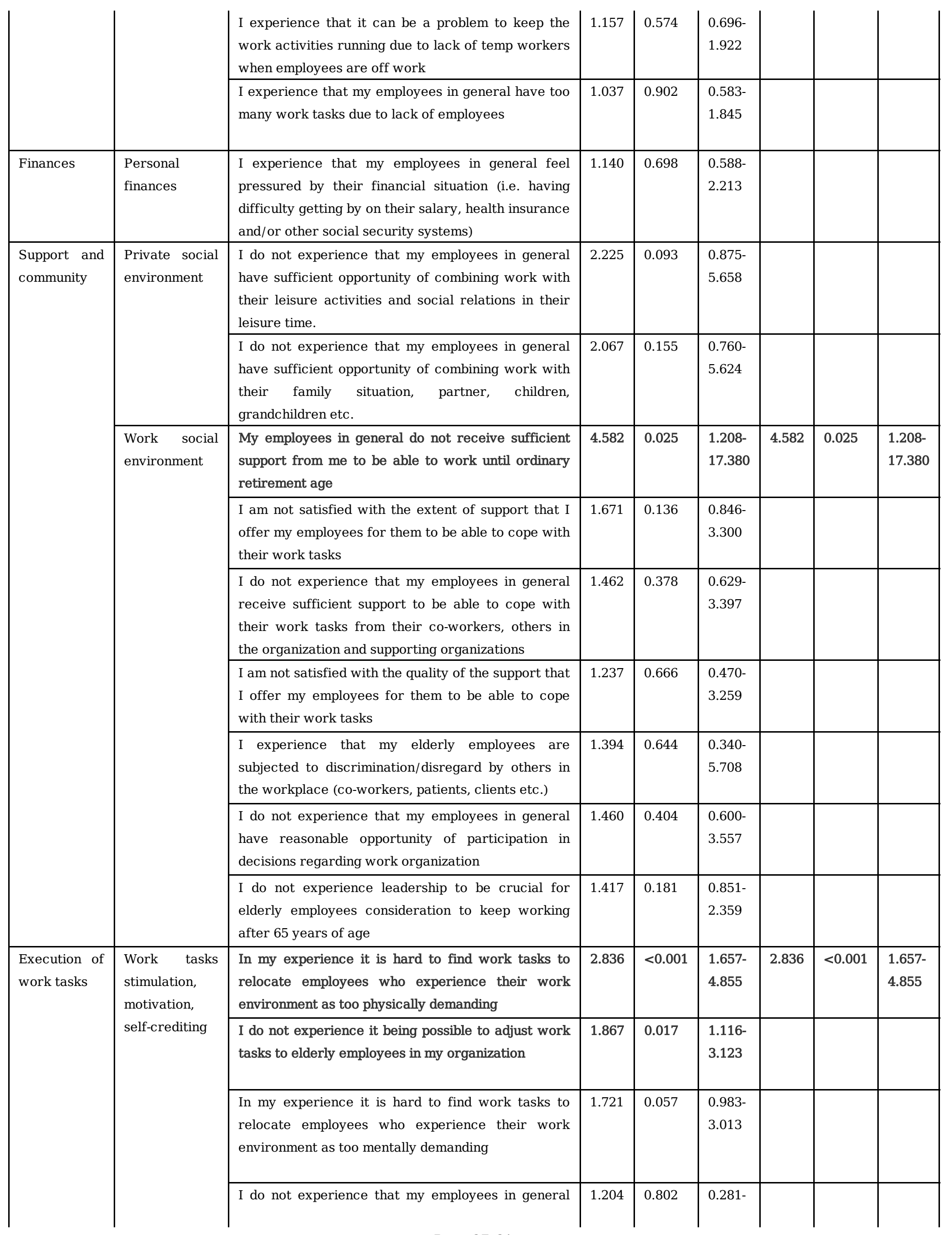

Page 27/31 


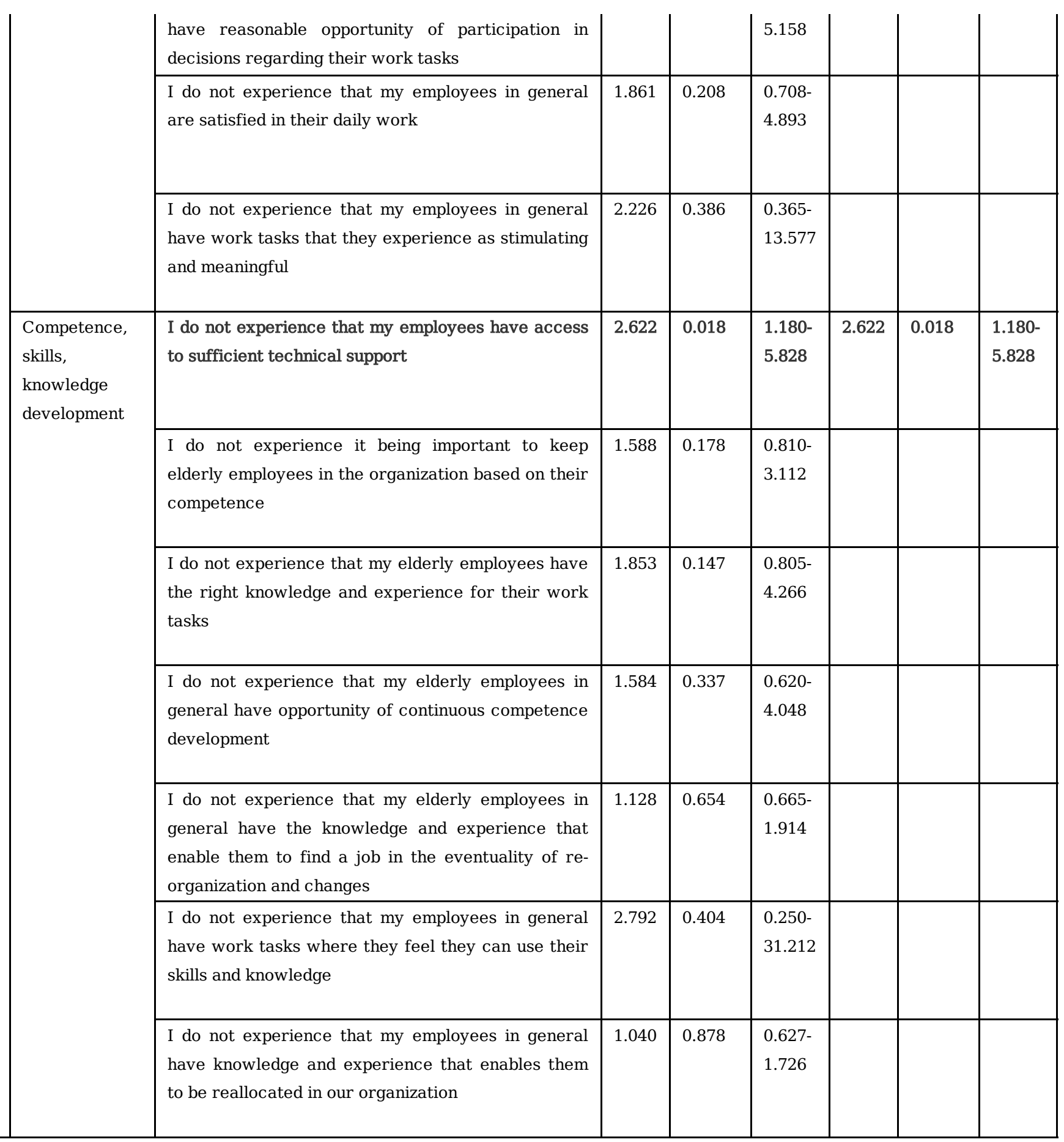

Table 7. The final multivariate model distributions regarding all the determinant areas combined and whether the managers believe their employees' 'want to work' outcome for the statements. The corresponding odds ratios (OR), significant value (P) and 95\% confidence intervals (CI) obtained from logistic regression. ORs in the multivariate model indicate the statements relation to whether the managers believe their employees' want to work until 65 years of age or beyond. 


\begin{tabular}{|c|c|c|c|c|c|}
\hline \multirow[t]{2}{*}{$\begin{array}{l}\text { Determinant } \\
\text { sphere }\end{array}$} & \multirow[t]{2}{*}{ Determinant areas } & \multirow[t]{2}{*}{ Statement } & \multicolumn{3}{|c|}{$\begin{array}{l}\text { Multivariate model in } \\
\text { the determent area }\end{array}$} \\
\hline & & & OR & $\mathrm{P}$ & $\begin{array}{l}95 \% \\
\text { CI }\end{array}$ \\
\hline \multirow{4}{*}{$\begin{array}{l}\text { The work } \\
\text { environments } \\
\text { health effect }\end{array}$} & $\begin{array}{l}\text { Health, diagnoses, } \\
\text { function variations }\end{array}$ & - & & & \\
\hline & $\begin{array}{l}\text { Physical work } \\
\text { environment }\end{array}$ & - & & & \\
\hline & $\begin{array}{l}\text { Mental work } \\
\text { environment }\end{array}$ & - & & & \\
\hline & $\begin{array}{l}\text { Work schedule, work } \\
\text { pace and recuperation }\end{array}$ & - & & & \\
\hline Finances & Personal finances & - & & & \\
\hline \multirow[t]{2}{*}{$\begin{array}{l}\text { Support and } \\
\text { community }\end{array}$} & $\begin{array}{l}\text { Private social } \\
\text { environment }\end{array}$ & - & & & \\
\hline & $\begin{array}{l}\text { Work social } \\
\text { environment }\end{array}$ & $\begin{array}{l}\text { My employees in general do not receive sufficient support from me } \\
\text { to be able to work until ordinary retirement age }\end{array}$ & 4.972 & 0.022 & $\begin{array}{l}1.263- \\
19.574\end{array}$ \\
\hline \multirow[t]{2}{*}{$\begin{array}{l}\text { Execution of } \\
\text { work tasks }\end{array}$} & $\begin{array}{l}\text { Work tasks stimulation, } \\
\text { motivation, self- } \\
\text { crediting }\end{array}$ & $\begin{array}{l}\text { In my experience it is hard to find work tasks to relocate employees } \\
\text { who experience their work environment as too physically } \\
\text { demanding }\end{array}$ & 2.812 & $<0.001$ & $\begin{array}{l}1.621- \\
4.872\end{array}$ \\
\hline & $\begin{array}{l}\text { Competence, skills, } \\
\text { knowledge } \\
\text { development }\end{array}$ & - & & & \\
\hline
\end{tabular}

Table 8. Measure statements associated to the managers' belief that their employees 'want to work' outcome for the statements. The corresponding odds ratios (OR), significant value $(\mathrm{P})$ and 95\% confidence intervals (CI) obtained from logistic regression. ORs in the univariate estimates indicate different measures in relation to the managers' belief that their employees want to work until 65 years of age or beyond. 


\begin{tabular}{|c|c|c|c|c|c|}
\hline $\begin{array}{l}\text { Determinant } \\
\text { sphere }\end{array}$ & Determinant areas & $\begin{array}{l}\text { Measures to increase employees' ability so they want to work for } 65 \\
\text { years or longer }\end{array}$ & OR & $\mathrm{P}$ & $\begin{array}{l}95 \% \\
\text { CI }\end{array}$ \\
\hline \multirow{11}{*}{$\begin{array}{l}\text { The work } \\
\text { environments } \\
\text { health effect }\end{array}$} & $\begin{array}{l}\text { Health, diagnoses, } \\
\text { function variations }\end{array}$ & $\begin{array}{l}\text { Compulsory exercise/health care to keep employees in mental and } \\
\text { physical shape until an older age }\end{array}$ & 1.285 & 0.330 & $\begin{array}{l}0.776- \\
2.129\end{array}$ \\
\hline & \multirow[t]{2}{*}{$\begin{array}{l}\text { Physical work } \\
\text { environment }\end{array}$} & Decrease of physical work demands & 1.541 & 0.103 & $\begin{array}{l}0.917- \\
2.592\end{array}$ \\
\hline & & $\begin{array}{l}\text { Rotation between different work tasks to decrease physical work load } \\
\text { and strain }\end{array}$ & 1.089 & 0.768 & $\begin{array}{l}0.618- \\
1.918\end{array}$ \\
\hline & \multirow[t]{3}{*}{$\begin{array}{l}\text { Mental work } \\
\text { environment }\end{array}$} & Decrease of mental work demands & 1.562 & 0.085 & $\begin{array}{l}0.941- \\
2.593\end{array}$ \\
\hline & & Increased self-monitoring of work & 1.372 & 0.235 & $\begin{array}{l}0.814- \\
2.311\end{array}$ \\
\hline & & $\begin{array}{l}\text { Rotation between different work tasks to decrease mental work load } \\
\text { and strain }\end{array}$ & 1.261 & 0.380 & $\begin{array}{l}0.752- \\
2.115\end{array}$ \\
\hline & \multirow[t]{5}{*}{$\begin{array}{l}\text { Work schedule, work } \\
\text { pace and recuperation }\end{array}$} & Decrease of work pace & 2.147 & 0.014 & $\begin{array}{l}1.169- \\
3.936\end{array}$ \\
\hline & & Increased time for recuperation between work shifts & 1.719 & 0.037 & $\begin{array}{l}1.032- \\
2.862\end{array}$ \\
\hline & & Shorter working hours & 1.761 & 0.144 & $\begin{array}{l}0.824- \\
3.763\end{array}$ \\
\hline & & Being able to take breaks when needed & 1.431 & 0.176 & $\begin{array}{l}0.852- \\
2.402\end{array}$ \\
\hline & & Change in the organization of work hours & 1.372 & 0.230 & $\begin{array}{l}0.819- \\
2.300\end{array}$ \\
\hline \multirow[t]{2}{*}{ Finances } & \multirow[t]{2}{*}{ Personal finances } & Higher salary & 1.677 & 0.070 & $\begin{array}{l}0.956- \\
2.933\end{array}$ \\
\hline & & Decreased pension to keep employees from retiring too early & 1.171 & 0.643 & $\begin{array}{l}0.601- \\
2.282\end{array}$ \\
\hline \multirow[t]{3}{*}{$\begin{array}{ll}\text { Support } & \text { and } \\
\text { community } & \end{array}$} & $\begin{array}{l}\text { Private social } \\
\text { environment }\end{array}$ & - & & & \\
\hline & \multirow[t]{2}{*}{$\begin{array}{l}\text { Work social } \\
\text { environment }\end{array}$} & Increased well-being and unity & 1.611 & 0.089 & $\begin{array}{l}0.930- \\
2.788\end{array}$ \\
\hline & & Increased participation at work & 1.473 & 0.147 & $\begin{array}{l}0.873- \\
2.485\end{array}$ \\
\hline \multirow[t]{6}{*}{$\begin{array}{l}\text { Execution } \quad \text { of } \\
\text { work tasks }\end{array}$} & \multirow{6}{*}{$\begin{array}{l}\text { Work tasks } \\
\text { stimulation, } \\
\text { motivation, self- } \\
\text { crediting }\end{array}$} & Increased work satisfaction & 1.379 & 0.246 & $\begin{array}{l}0.801- \\
2.374\end{array}$ \\
\hline & & Other work tasks in the work place when needed & 1.284 & 0.338 & $\begin{array}{l}0.770- \\
2.141\end{array}$ \\
\hline & & Increased opportunity of development at work & 1.249 & 0.391 & $\begin{array}{l}0.752- \\
2.077\end{array}$ \\
\hline & & $\begin{array}{l}\text { Increased opportunity of changing occupation and career at an older } \\
\text { age }\end{array}$ & 1.212 & 0.461 & $\begin{array}{l}0.726- \\
2.023\end{array}$ \\
\hline & & Increased career opportunities & 1.205 & 0.489 & $\begin{array}{l}0.711- \\
2.041\end{array}$ \\
\hline & & $\begin{array}{l}\text { That employees in increased extent can focus on work tasks that they } \\
\text { themselves experience as being the most important and interesting in } \\
\text { their work }\end{array}$ & 1.166 & 0.555 & $\begin{array}{l}0.700- \\
1.944\end{array}$ \\
\hline
\end{tabular}




\begin{tabular}{|c|c|c|c|c|}
\hline & New job within their occupational area & 1.158 & 0.618 & $\begin{array}{l}0.651- \\
2.061\end{array}$ \\
\hline & $\begin{array}{l}\text { Rotation between different work tasks and activities to increase } \\
\text { stimulation }\end{array}$ & 1.077 & 0.779 & $\begin{array}{l}0.643- \\
1.802\end{array}$ \\
\hline \multirow{3}{*}{$\begin{array}{l}\text { Competence, skills, } \\
\text { knowledge } \\
\text { development }\end{array}$} & Through, for the employee, need-oriented competence development & 1.315 & 0.288 & $\begin{array}{l}0.794- \\
2.180\end{array}$ \\
\hline & Opportunity of new knowledge & 1.139 & 0.615 & $\begin{array}{l}0.685- \\
1.894\end{array}$ \\
\hline & Through, for the work place, need-oriented competence development & 1.066 & 0.803 & $\begin{array}{l}0.644- \\
1.767\end{array}$ \\
\hline
\end{tabular}

